Journal of Advanced Research in Fluid Mechanics and Thermal Sciences

\title{
Improving Energy Efficiency in Supermarkets by Retrofitting Low-E Glass Doors for Open Refrigeration Systems with Digital Semi Hermetic Compressor
}

\author{
Piyanut Saengsikhiao ${ }^{1}$, Juntakan Taweekun ${ }^{2, *}$ \\ Energy Technology Program, Faculty of Engineering, Prince of Songkla University, Hat Yai, Songkhla 90112, Thailand \\ 2 Department of Mechanical and Mechatronics Engineering, Faculty of Engineering, Prince of Songkla University, Hat Yai, Songkhla 90112, \\ Thailand
}

\section{ARTICLE INFO}

\section{Article history:}

Received 8 September 2020

Received in revised form 7 December 2020

Accepted 8 December 2020

Available online 20 April 2021

\section{Keywords:}

Refrigeration system; energy efficiency; Low-E glass doors; open refrigeration system; retrofitting; digital semi hermetic compressor

\section{ABSTRACT}

This research will be presenting energy efficiency improvement options by retrofitting doors for open refrigeration systems in Central Thailand supermarkets that open during the daytime (06:00 am - 06:00 pm), and are closed during the night-time (00:00 am $-6: 00 \mathrm{am})$. The materials and methods used consisted of 15 open refrigeration cabinets with 82 retrofitted doors supported by 41 frames, with the temperature set at medium. The power consumption was indicated in $\mathrm{kW}, \mathrm{kWh}$ through a power meter data logger for analysis and summarization. The investment required was €21,694 /store, while the payback period of this research was determined to be at 14 months. The cost of energy savings was found to be within a period of 1.1 years, at the rate of $192,220 \mathrm{kWh} /$ year or $€ 18,503$ annually. The retrofitted doors is expected to reduce the cooling load and over-burdening of the compressor. The research found that the most viable solution was to use a digital semi-hermetic compressor that can operate in unload and full load status, that was being controlled by the evaporator temperature (TEV) which was set at -10 degree, the condenser temperature (TCD) set at 38 degrees, and the superheat temperature (TSH) at 10 degrees. In the unload status, the power consumption of the digital semi hermetic compressor will decrease by $50 \%$, which has a significant impact for energy savings and is important for night-time when low cooling load is required whereby the compressor's multiple start-stop cycles are not required. The investment for a digital semi-hermetic compressor was determined to be $€ 7,800 /$ store, and is able to yield energy savings of up to $26,890 \mathrm{kWh} /$ year, or $€ 2,589$ annually, with a payback period of 2.9 years.

\section{Introduction}

Energy use in Thailand's business sector is ranked second among overall energy users in the country and is thus being targeted for energy-saving options [1]. The number of supermarkets in Thailand is numbered to more than 1,500 locations in 2020, and this number continuously increases annually [2]. The majority are open 18-24 hours a day, thus ranking the retail sector to be the fourth

\footnotetext{
${ }^{*}$ Corresponding author.

E-mail address: jantakan.t@psu.ac.th
}

https://doi.org/10.37934/arfmts.82.1.145157 
largest consumer of energy in the business sector, and consumes more energy than residences do [3]. The components that contribute to supermarkets' energy consumption in Thailand, ranked from the highest to the lowest, are: refrigeration systems, air-conditioning systems, electrical equipment, and lighting $[4,5]$. However, proportions of energy use in the supermarkets in Thailand were previously ranked [6]. The best options for reducing energy consumption in supermarkets in Thailand are high energy efficiency and an efficient energy-management system. An excellent example of energy savings in refrigeration systems that energy savings in refrigeration systems can be achieved through decreased compressor power consumption, as this is the major component that utilizes the most energy [7].

In the open showcase, the air curtain system can lower the cabinet's inside air temperature, as shown in Figure 1 [8,9]. 70\% of the airflow supply that originates from the air curtains is used to maintain the temperature of the cabinet, while the remaining $30 \%$ airflow supply from the back-wall panel is used for cooling of the products. The entire airflow supply is then continuously recycled back towards the air grill. Several conditions also contribute towards affecting the air curtains, for example, (i) blockages of the recycled airflow supply, (ii) customers picking up products, (iii) temperature and humidity surrounding the sales area, (iv) wind forming in the air-conditioning return and supply, and ( $v$ ) staff storing products. All of these factors affect the performance of the refrigerator and the compressor's power consumption [10,11]. Refrigerators with doors can operate and perform more efficiently than open refrigeration systems $[12,13]$ as they are not affected by the above-mentioned 5 conditions, as shown in Figure 2 below [14]. The comparison clearly indicates the cabinet temperature simulation between open and closed refrigerators, whereby refrigerators with doors being able to maintain a constant temperature more efficiently. In addition, it also indicates that there is not much variation between the minimum and maximum temperature. This research will present on how to improve on energy efficiency by retrofitting doors for open refrigerators in central Thailand supermarkets. Thus, customers will be able to have access to quality products, while at the same time, providing retail companies and suppliers with reliability.
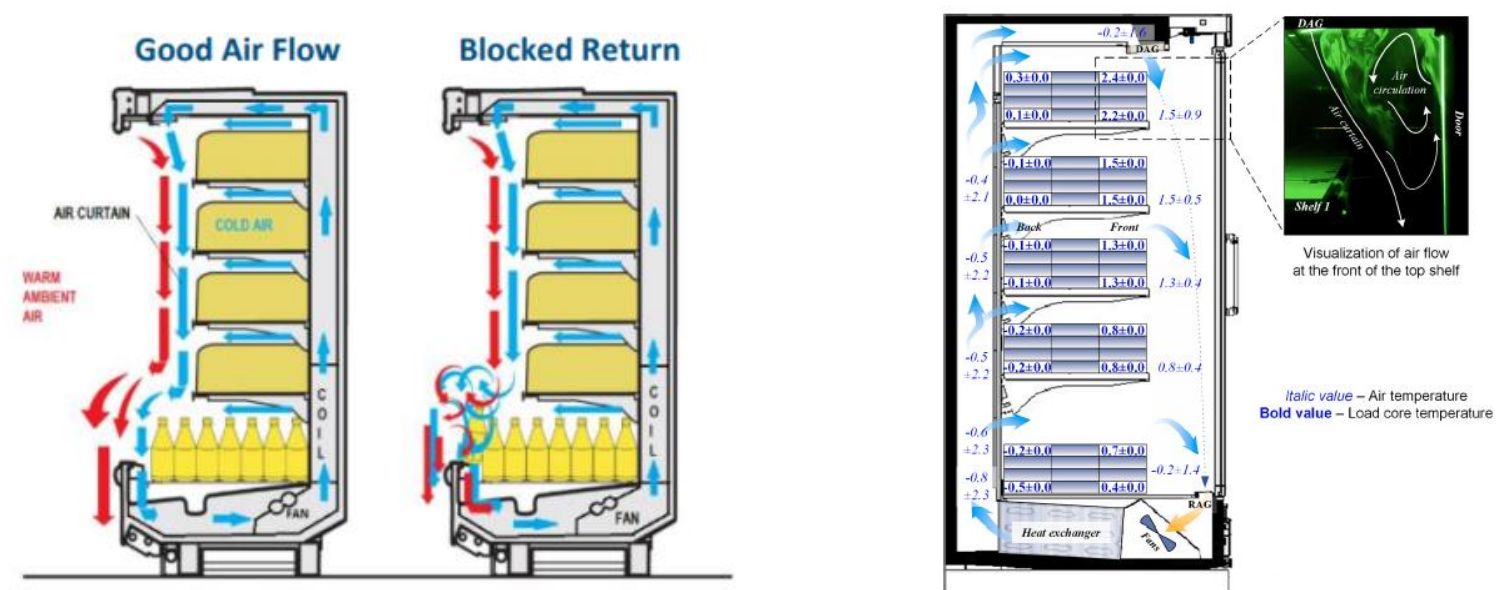

Fig. 1. Standard Workflow of an open and closed refrigeration system $[8,9]$ 

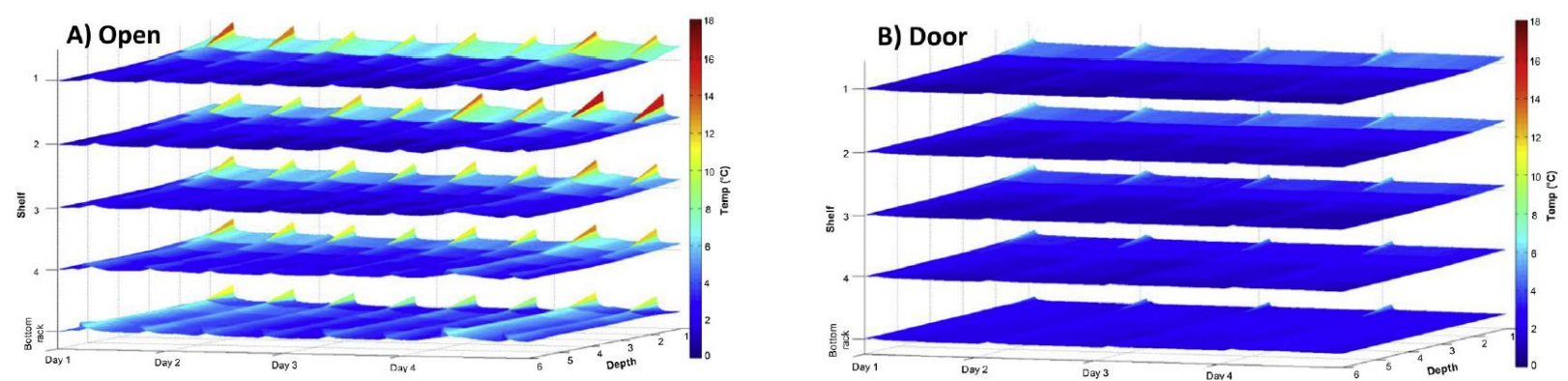

Fig. 2. Comparison of cabinet temperature between (a) open and (b) closed refrigeration systems [15]

\section{Materials and Methods}

\subsection{Low-E Glass Door}

The Low-E glass door for cabinets will reduce the compressor power consumption in order to protect heating or cooling, as shown in Figure 3 below. The Low-E feature consists of a coating filler that reduces transmission and absorption of infrared radiation [16,17]. The most common type of a Low-E glass panel uses two or three panes of glass separated by a gap filled with gas in the refrigerator $[18,19]$. The main objective is to reduce the transmission and absorption of infrared radiation [20]. This research used a two-layer Low-E glass with a gas gap for retrofits for open refrigeration systems, as showed in the refrigerator. The percentage of transmission for Low-E glass at all layer types was found to be lower than regular glass, as shown in Figure 4 below [21].

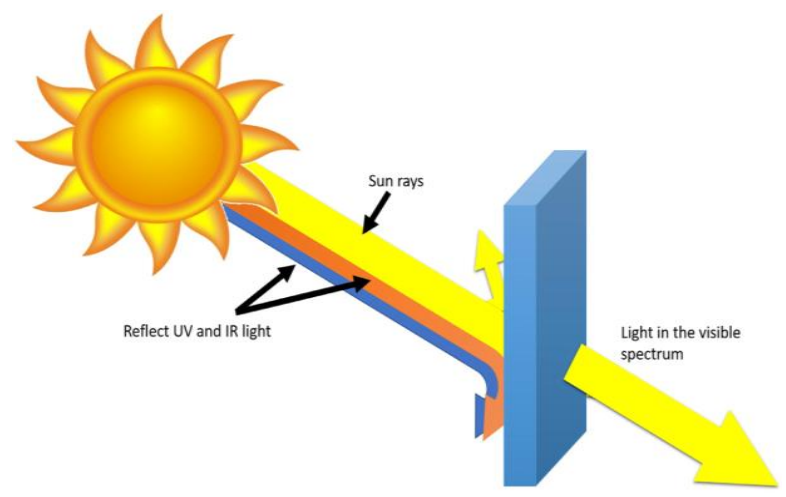

Fig. 3. Low-E filters on windows [21]

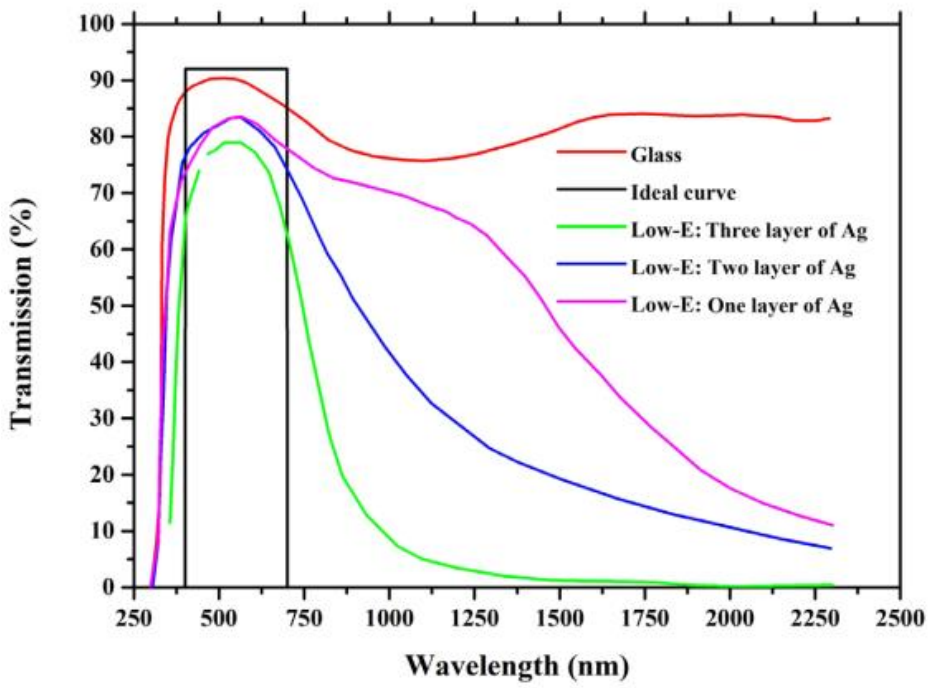

Fig. 4. Transmittance of different Low-E filters [21] 
The 15 open refrigerators with retrofitted doors were outfitted with 82 doors supported by 41 frames, with the temperature set at medium. The cabinet was used for storing sausages, dairy, and meat products, that evaporated at temperatures of $-8,-8,-10$ degrees Celsius, and a cabinet temperature of $(+2 /+4),(+2 /+4),(+0 /+2)$ degrees Celsius respectively. The cabinet dimensions were $3,750 \mathrm{~mm}$. (L) $\times 800 \mathrm{~mm}$. (D) $\times 2,000 \mathrm{~mm}$. (H) and 2,500 mm. (L) $\times 800 \mathrm{~mm}$. (D) $\times 2,000 \mathrm{~mm}$. (H), and consisted of 6 doors supported by 3 frames, and 4 doors supported by 2 frames, respectively. The power consumption measurement is indicated in $\mathrm{kW}$ and $\mathrm{kWh}$, by the power meter analysis for data logger, and the summary of medium temperature refrigeration system. The sample images for the retrofitted doors for the open refrigeration systems, are illustrated in Figure 5 and Figure 6.
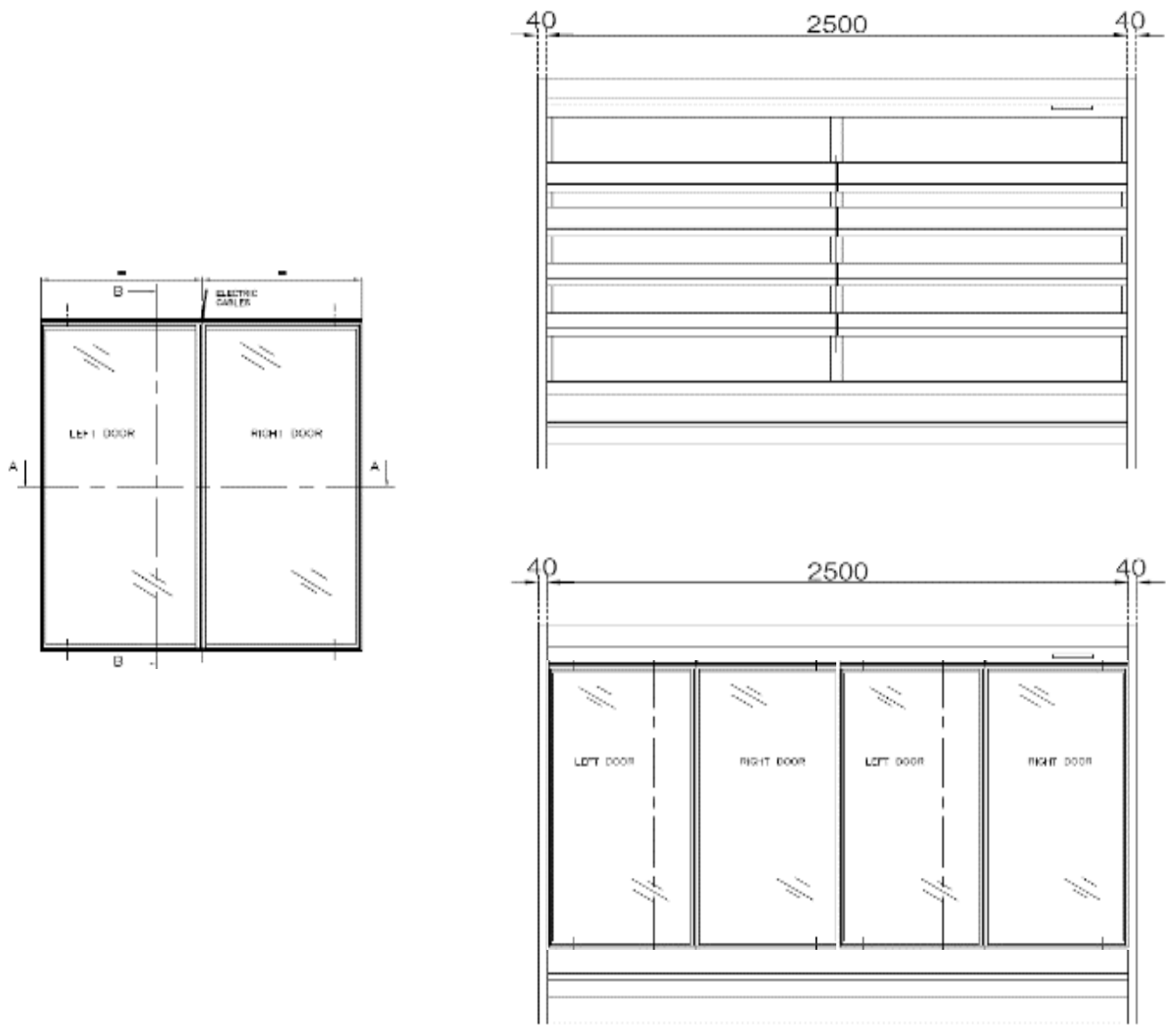

Fig. 5. Doors and refrigerator drawing

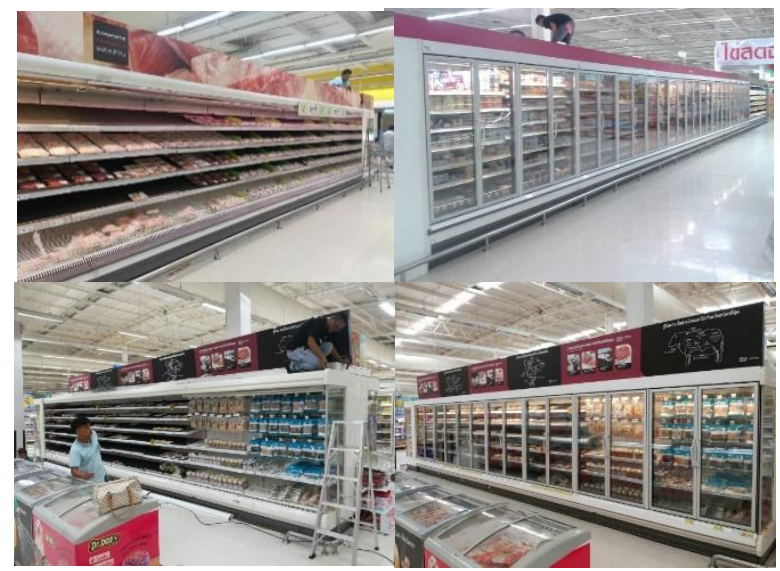

Fig. 6. Before and after retrofits 


\subsection{Digital Semi-hermetic Compressor}

The semi-hermetic compressor can operate both in unload and full load status, as shown in Figure 4 below. It is controlled by an evaporator temperature (TEV) set at -10 degree, a condenser temperature (TCD) set at 38 degrees, and a superheat temperature (TSH) at 10 degrees. In unload status, the power consumption for the digital semi-hermetic compressor was found to decrease by $50 \%$, which had a significant impact towards energy saving and is important for night-time when low cooling load is required and the compressor's multiple start-stop cycles are not required [22-24]. Workflow of the digital semi-hermetic compressor is illustrated in Figure 7 and Figure 8, and the fixed-speed compressor rack compressor and digital scroll are illustrated in Figure 9, Figure 10, and Figure 11.
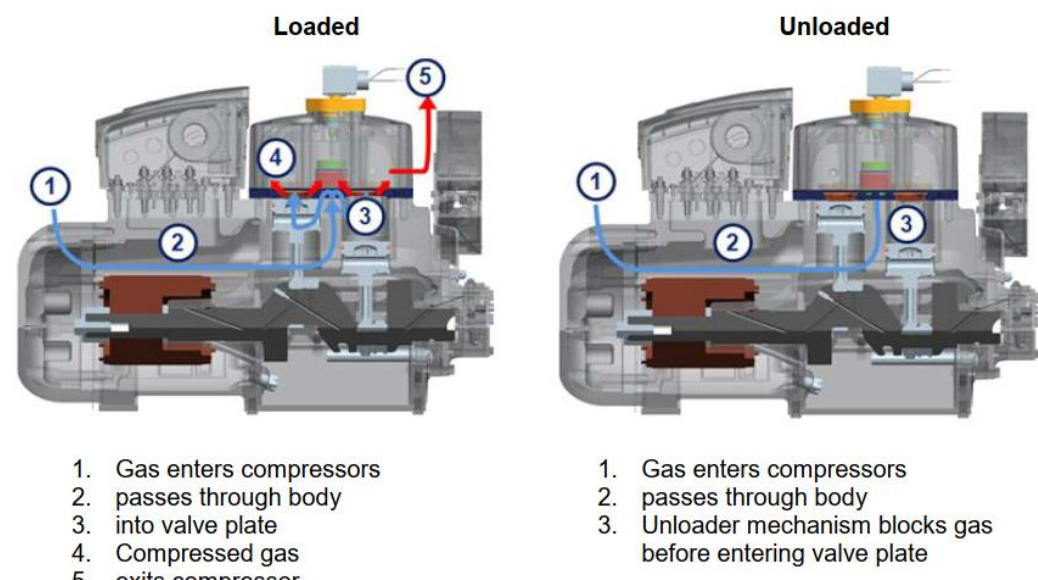

1. Gas enters compressors

2. passes through body

3. into valve plate

4. Compressed gas

5. exits compressor

Unloader mechanism blocks gas

before entering valve plate

Fig. 7. Workflow of the digital semi-hermetic compressor
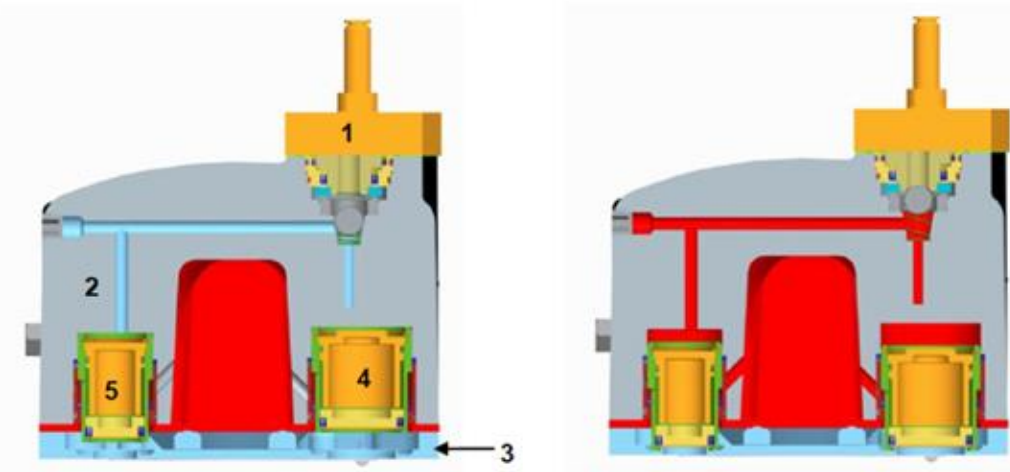

$1=$ Solenoid valve

$\mathbf{2}=$ Cylinder head

$1=$ Solenoid valve

$2=$ Cylinder head

$3=$ Valve plate

$4 \& 5$ = Unloading piston

$3=$ Valve plate

$4 \& 5$ = Unloading piston
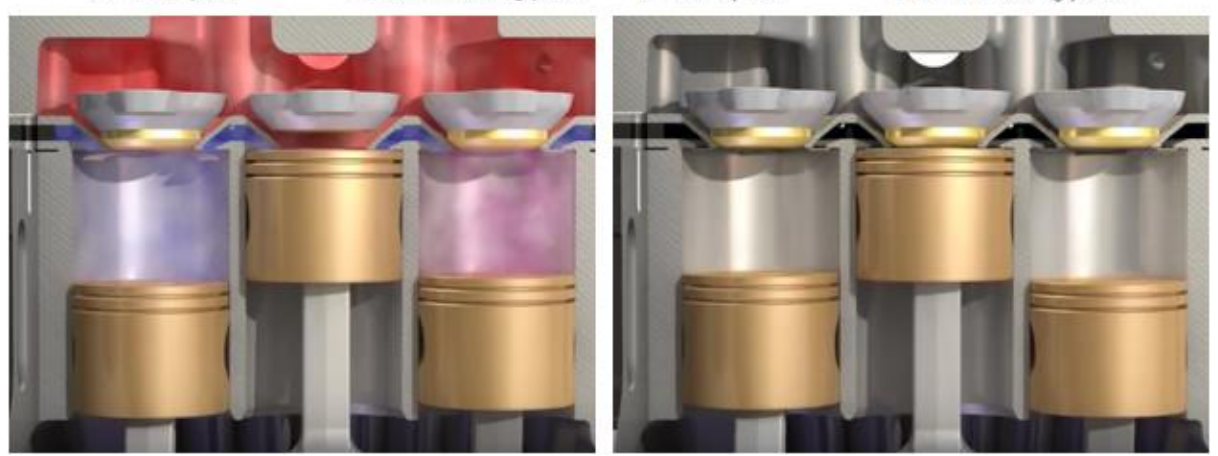

Fig. 8. Operation of digital semi-hermetic compressor 


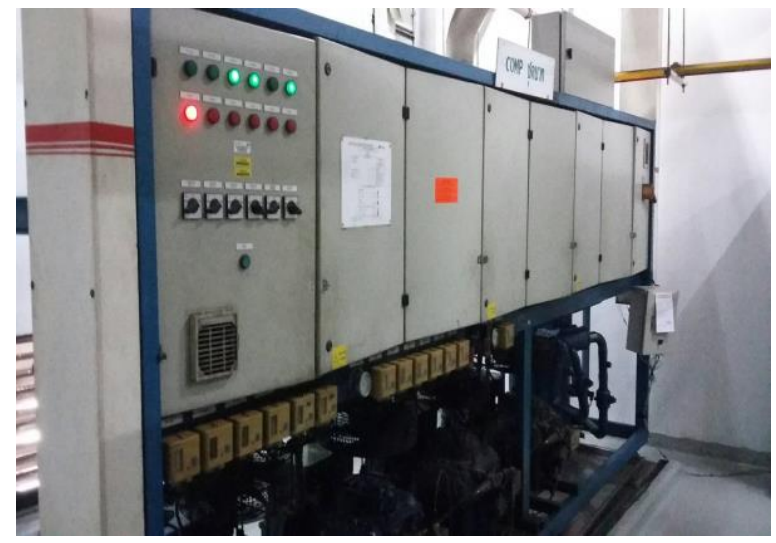

Fig. 9. Compressor Rack

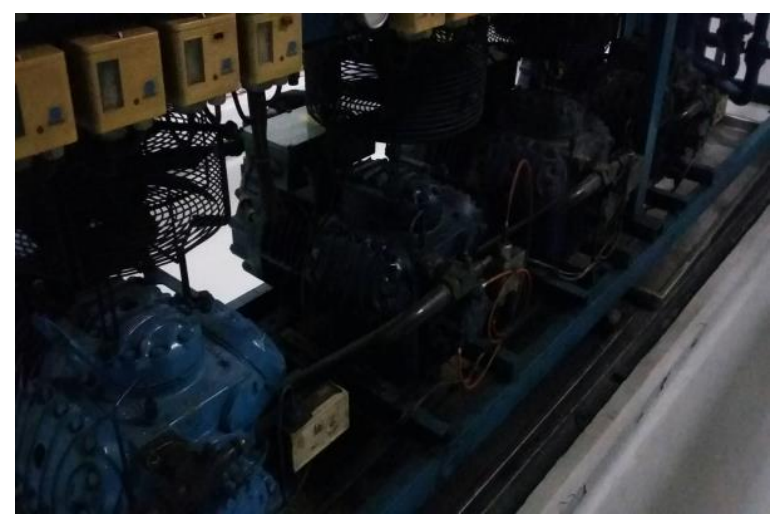

Fig. 10. Fix Speed Compressor Rack
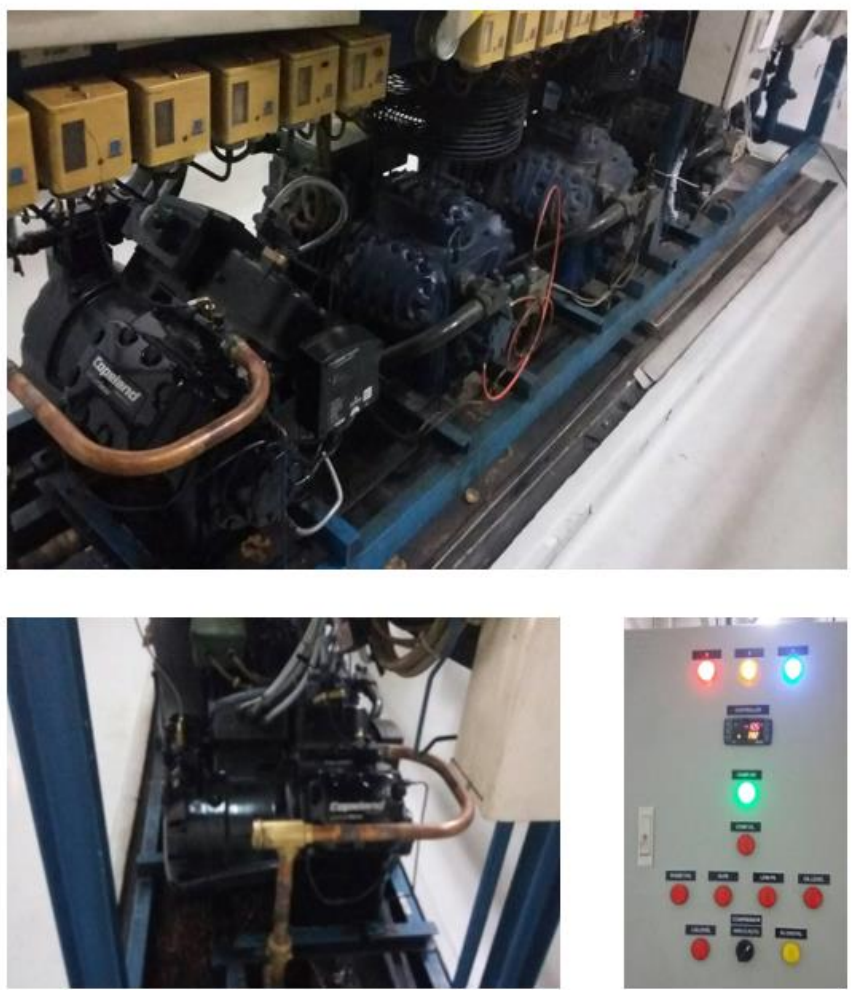

Fig. 11. Digital Compressor Rack with Distal compressor and digital controller 
A power meter data logger and temperature data logger were used to measured power consumption (W), voltage (V), current (I), power factor (PF), frequency $(\mathrm{Hz})$, evaporator temperature (TEV), condenser temperature (TCD), liquid temperature (TLQ), sub cool temperature (TSC), gas temperature (TG), and superheat temperature (TSH) [25-27].

\section{Results and Discussion}

\subsection{Energy Efficiency Improvement by Low-E Glass Door}

The power consumption rate before and after retrofitting doors in Figure 12 and Figure 13, shows power consumption during daytime operations (06:00 am - 06:00 pm), and when the supermarket closes during the night-time (00:00 am - 06:00 am). Before retrofitting doors, the average power consumption per 7-day period was 1,388 kWh/day, i.e., $997 \mathrm{kWh} /$ day during daytime, and 391 $\mathrm{kWh} /$ day during night-time. After retrofitting, the average power consumption per 7-day period was $812 \mathrm{kWh} /$ day, i.e., $579 \mathrm{kWh} /$ day during daytime, and $233 \mathrm{kWh} /$ day during night-time. The average power consumption savings per 7-day period after retrofitting doors was $576 \mathrm{kWh} /$ day, or $39.67 \%$, a daytime decrease of $418 \mathrm{kWh} /$ day, or $41.93 \%$, and a night-time decrease of $158 \mathrm{kWh} /$ day, or $33.24 \%$. Energy consumption during the daytime was higher than during the night-time due to the following factors; (i) opening hours of the store was longer than non-operating hours, (ii) during the night-time, the refrigerator was closed with the use of plastic curtains, (iii) the request cooling load during the daytime was more than during the night-time, and (iv) the sales area/ambient temperature during the night-time was more than during the daytime, however, there was also a large contrast of the humidity.

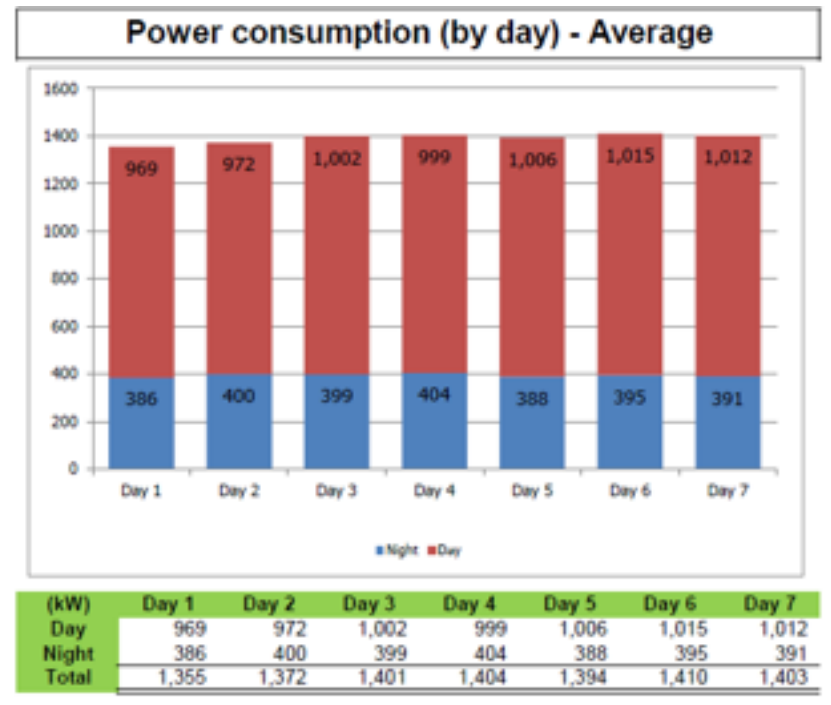

Before

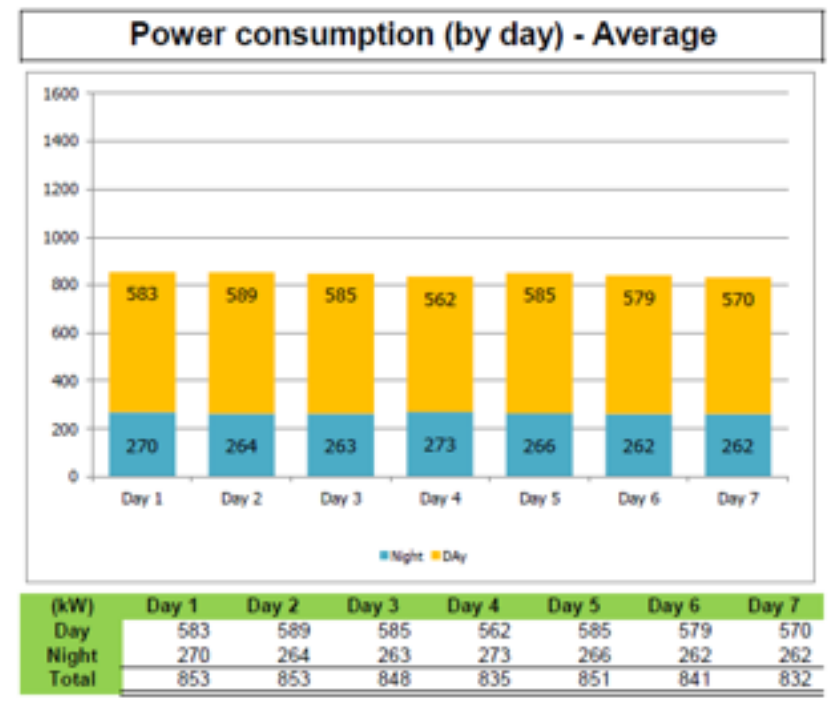

After

Fig. 12. Average power consumption per day, before and after door retrofits

Before retrofitting doors, the average power consumption per 7-day period was $111.62 \mathrm{~kW} /$ day, $62.29 \mathrm{~kW} /$ day during daytime, and $49.33 \mathrm{~kW} /$ day during night-time. After retrofitting of the doors, the average power consumption per 7-day period was $69.48 \mathrm{~kW} /$ day, $36.33 \mathrm{~kW} /$ day during daytime, and $33.15 \mathrm{~kW} /$ day during night-time, as shown in Figure 8 . The maximum and minimum power consumption before retrofitting doors was $83.25 \mathrm{~kW} /$ hour and $44.73 \mathrm{~kW} /$ hour respectively, a difference of $38.52 \mathrm{~kW} /$ hour, or $46.72 \%$. The maximum and minimum power consumption after retrofitting doors was found to be $33.15 \mathrm{~kW} /$ hour and $30.19 \mathrm{~kW} /$ hour respectively, a difference of 
$2.96 \mathrm{~kW} /$ hour, or $8.93 \%$. The difference in power consumption after retrofitting of the doors was found to be less than before the retrofit. This is due to 1) the normal cooling capacity load was more or less similar for both conditions, and 2) the cooling capacity may vary according to the product's temperature, surrounding area temperature and humidity, as well as, the effect of the customer's behavior towards selecting the products.

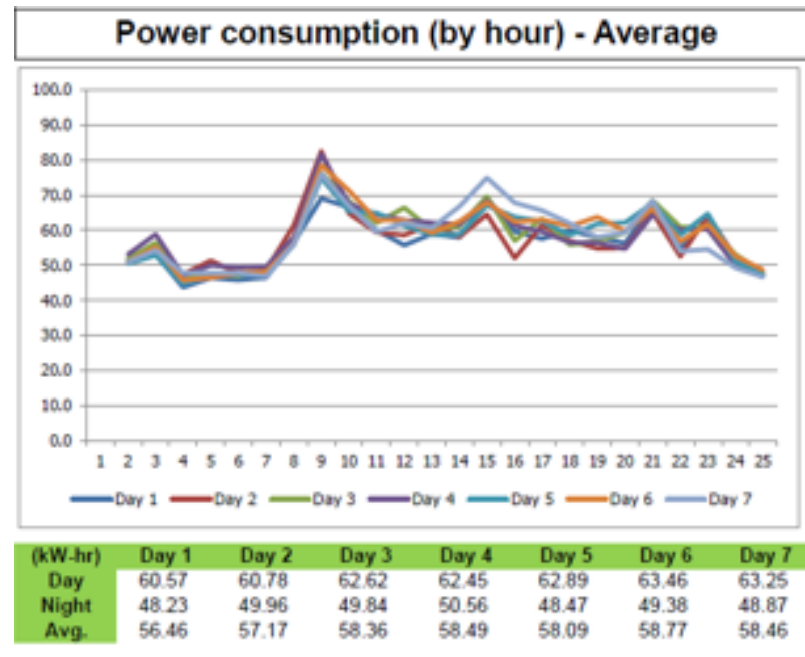

Before

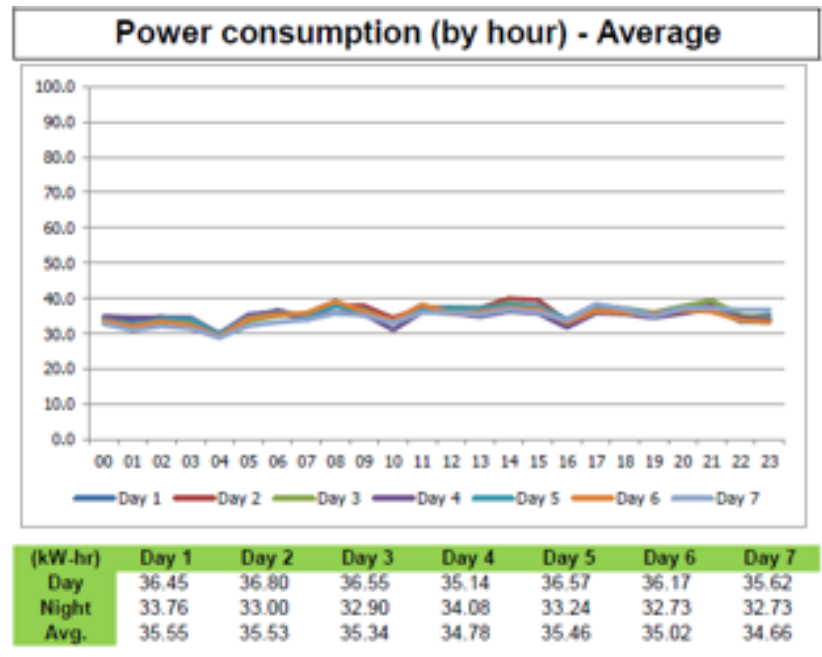

After

Fig. 13. Average power consumption per hour, before and after retrofits

The investment for this research was $€ 21,694$, which was used to retrofit 82 doors with 41 frames, with a payback period of 14 months. Within 1.1 year, the energy savings was determined to be 16,020 $\mathrm{kWh} /$ month $(192,220 \mathrm{kWh} /$ year), or $€ 1,542 /$ month ( $€ 18,504 /$ year). The cost of energy savings per frame and energy savings per door was 4,689 kWh/year, or €451/year, and 2,344 kWh/year or $€ 225 /$ year, respectively.

\subsection{Effects of the Refrigerator Door Retrofit}

The refrigerator door retrofit has a direct affect in reducing the cooling capacity load, as well as, operation of the compressor. The solution was to use a digital semi-hermetic compressor that can operate in both unload and full load status, that was controlled setting the evaporator temperature (TEV) at -10 degree, the condenser temperature (TCD) at 38 degrees, and the superheat temperature (TSH) at 10 degrees. During the unload status, the power consumption of the digital semi-hermetic compressor decreased by $50 \%$, and is important for night-time when low cooling load is required whereby the compressor's multiple start-stop cycles are not required. The daytime and night-time compressor's fix speed status comparison of the digital semi-hermetic compressor, are illustrated in Figure 14 and Figure 15. 


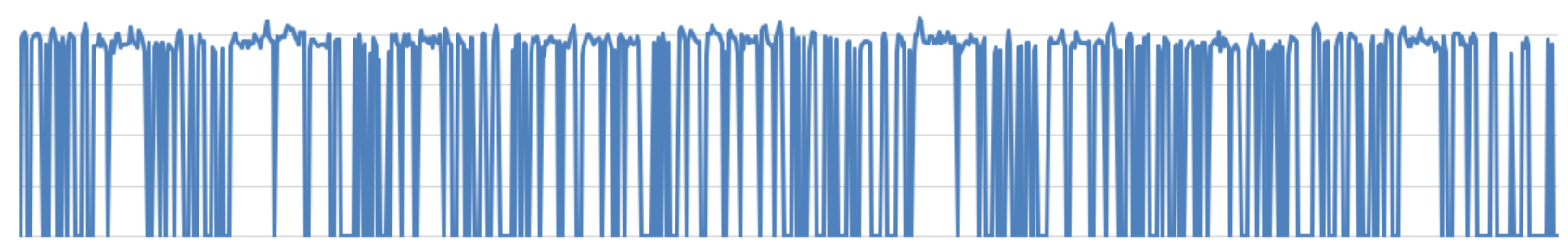

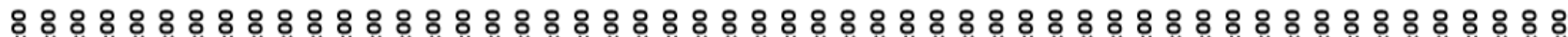

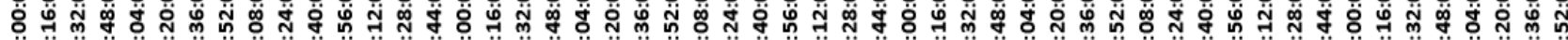

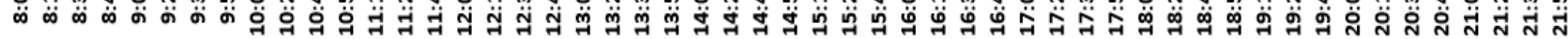

Day Time Digital Compressor Operating

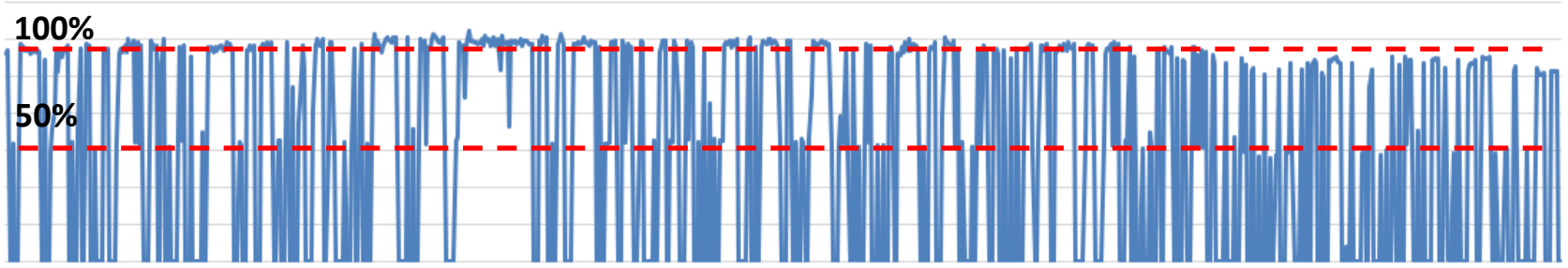

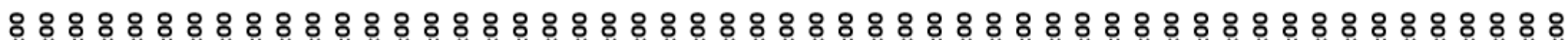

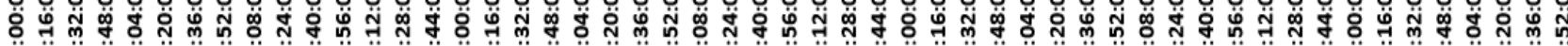

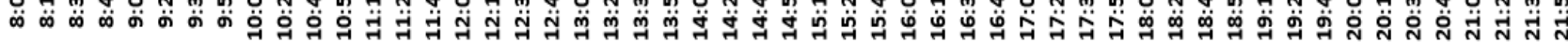

Fig. 14. The daytime compressor's fixed speed status comparison of the digital semi-hermetic compressor

Night Time Fix Speed Compressor Operating

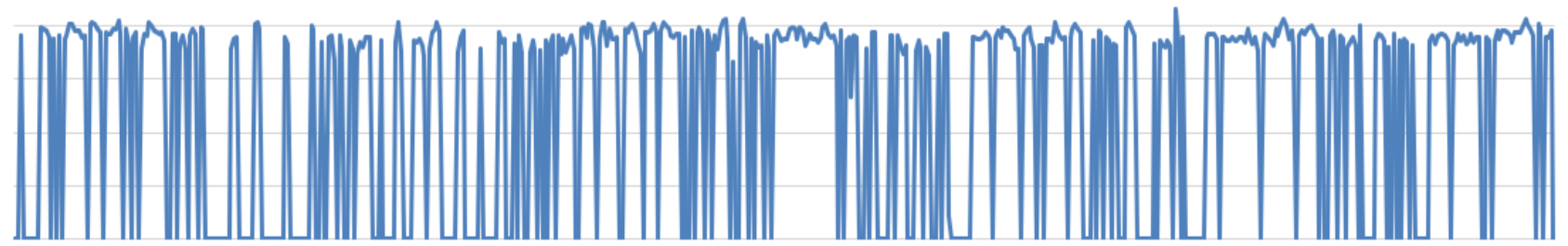

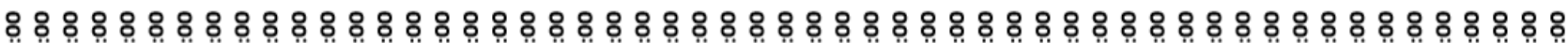

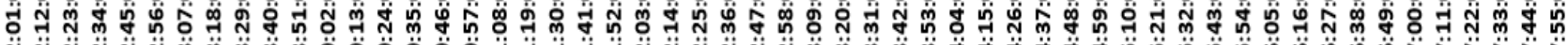

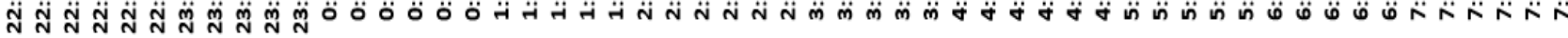

\section{Night Time Digital Compressor Operating}

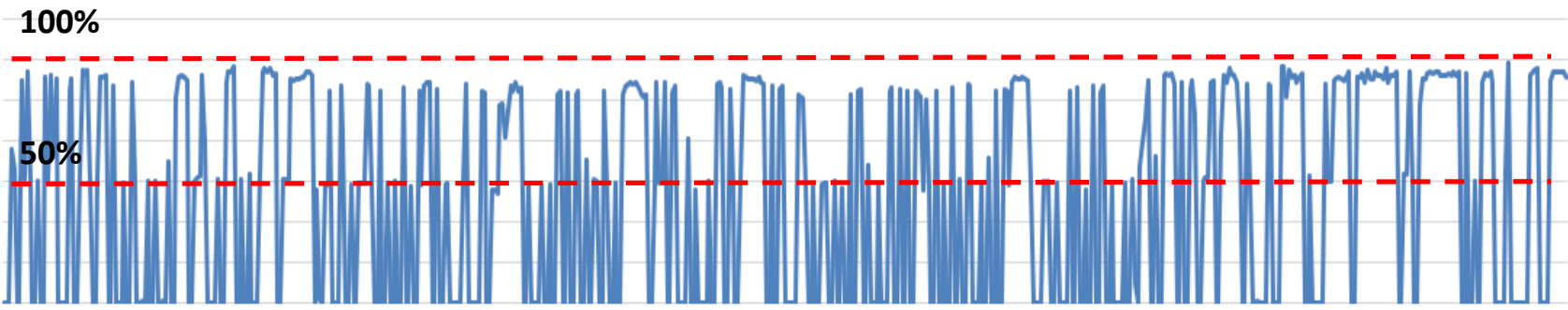

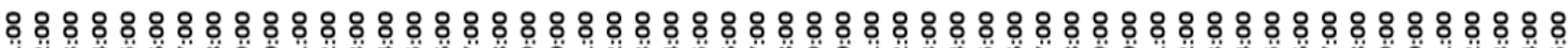

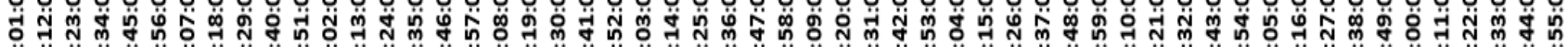

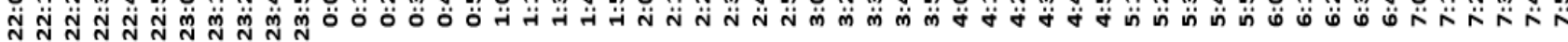

Fig. 15. The night-time compressor's fixed speed status comparison of the digital semi-hermetic compressor 


\subsection{Energy Efficiency Improvement by Digital Steam Compressor}

The fix speed semi-hermetic compressor will start its operation when the evaporator temperature is higher than -10 degree, as shown in Figure 16 below, and will cut off when the evaporator temperature goes below -10 degree. When the latter occurs (compressor cutting off at the evaporator temperature that is lower than -10 degree), the compressor will operate at an evaporator temperature until it reaches -20 degree where it will cut off immediately by a pump down, due to its unnecessity and its impact of the energy wasted by the compressor.

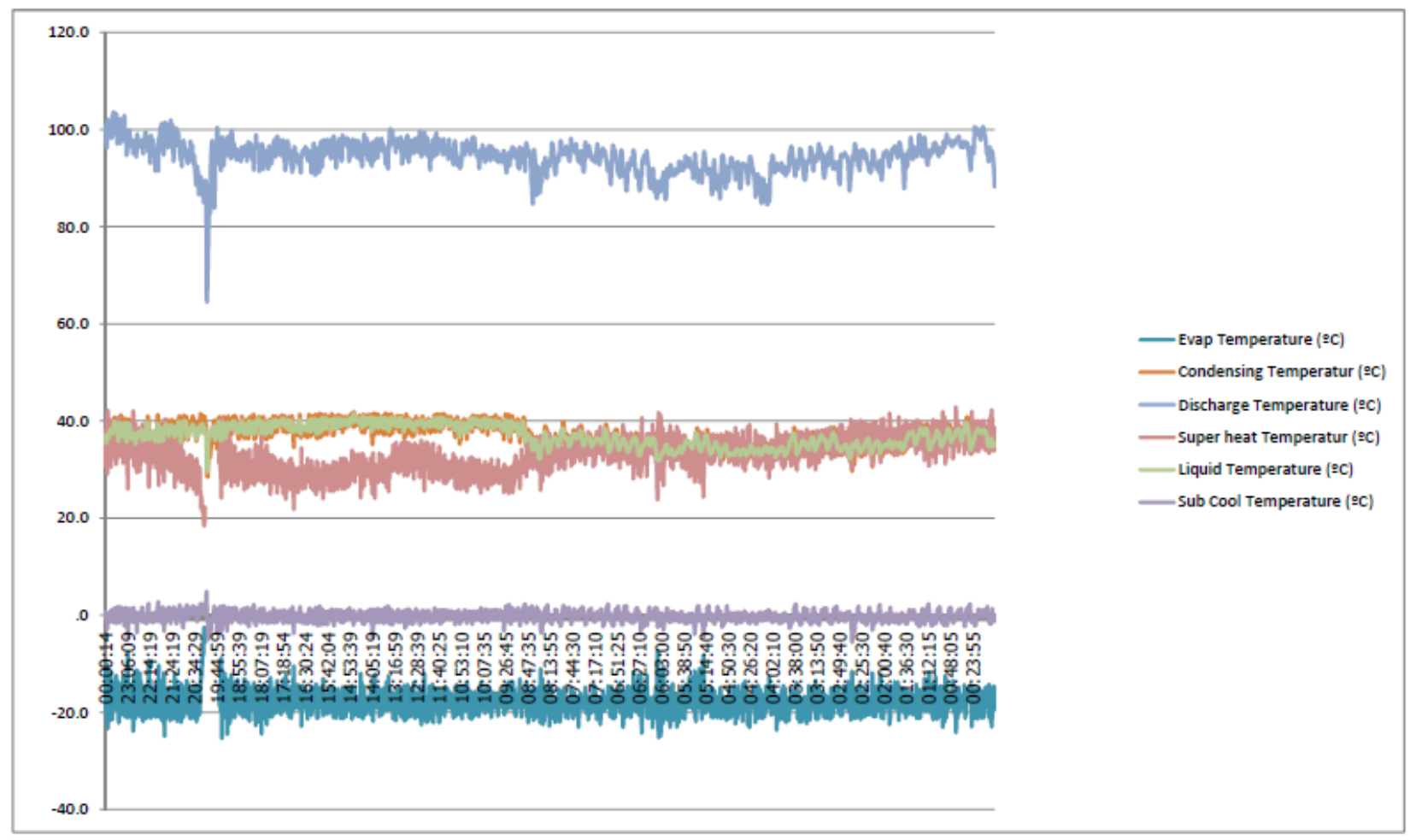

Fig. 16. Analysis of the fix speed semi-hermetic compressor temperature

The digital semi-hermetic compressor will start to operate when the evaporator temperature is higher than -10 degree, as shown in Figure 17 below, and will cut off when the evaporator temperature is lower than -10 degree. However, when the compressor starts to operate at an evaporator temperature that is lower than -10 degree, it will not cut off but will operate in an unload status, whereby the energy consumption is only at $50 \%$ of its normal capacity as the motor is only operating without the need of the compressor. The digital semi-hermetic compressor will operate at full load again once the evaporator temperature reaches a level that is higher than -10 degree. Comparison of the compressor's digital and fix speed status are illustrated in Figure 16 and Figure 17. The investment for a digital semi-hermetic compressor was determined to be $€ 7,800 /$ store, and is able to yield energy savings of up to $26,890 \mathrm{kWh} / \mathrm{year}$, or $€ 2,589$ annually, with a payback period of 2.9 years. 


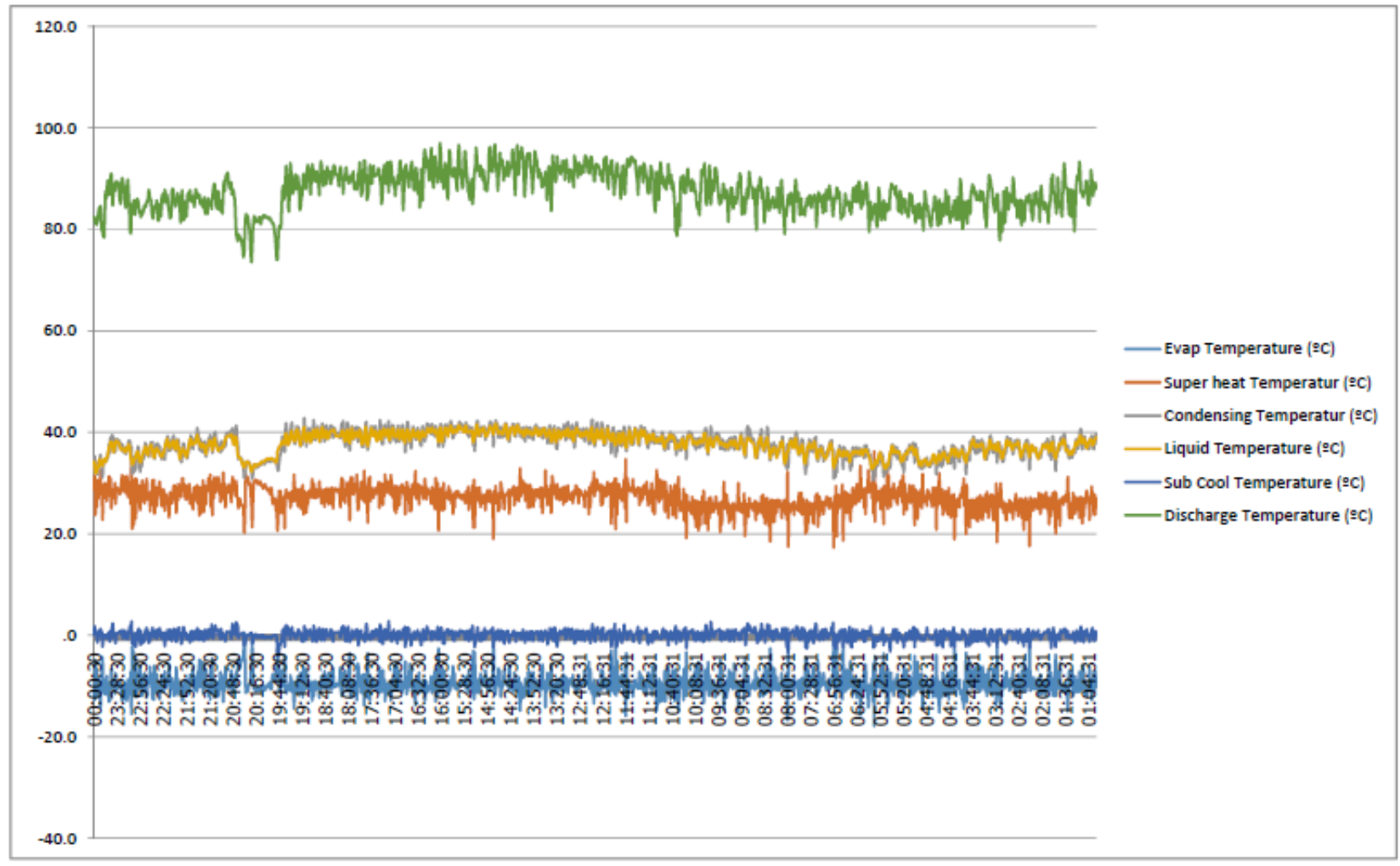

Fig. 17. Analysis of the fix speed semi-hermetic compressor temperature

\section{Conclusions}

For further recommendations, the researchers should apply other types of door retrofitting options for the open refrigeration systems, such as horizontal refrigerators and other door types. For example, use sliding doors that will result in energy savings, and retrofitting doors to other open refrigeration systems in convenience stores, which will be able to implement energy-saving options for approximately 20,000 stores all over Thailand.

\section{Acknowledgement}

This study was supported by the Prince of Songkla University and SANYO S.M.I. (Thailand) Co., Ltd.

\section{References}

[1] Kuo, Chung-Feng Jeffrey, Chieh-Hung Lin, and Ming-Hao Lee. "Analyze the energy consumption characteristics and affecting factors of Taiwan's convenience stores-using the big data mining approach." Energy and Buildings 168 (2018): 120-136. https://doi.org/10.1016/i.enbuild.2018.03.021

[2] Saengsikhiao, Piyanut, Juntakan Taweekun, Kittinan Maliwan, Somchai Sae-ung, and Thanansak Theppaya. "Investigation and Analysis of R463A as an Alternative Refrigerant to R404A with Lower Global Warming Potential." Energies 13, no. 6 (2020): 1514. https://doi.org/10.3390/en13061514

[3] Shen, Hanyan, Ke Xu, and James Freihaut. "A statistical study on energy performance of US convenience stores: Investigation of factors and bench marking on store energy use." Energy and Buildings 183 (2019): 792-802. https://doi.org/10.1016/i.enbuild.2018.10.018

[4] Tassou, S. A., Y. Ge, A. Hadawey, and Doug Marriott. "Energy consumption and conservation in food retailing." Applied Thermal Engineering 31, no. 2-3 (2011): 147-156. https://doi.org/10.1016/j.applthermaleng.2010.08.023

[5] Wang, An-Ping, and Pau-Lo Hsu. "The network-based energy management system for convenience stores." Energy and Buildings 40, no. 8 (2008): 1437-1445. https://doi.org/10.1016/i.enbuild.2008.01.007

[6] Chou, Ding-chin, Ching-Shan Chang, and Yong-Zhi Hsu. "Investigation and analysis of power consumption in convenience stores in Taiwan." Energy and Buildings 133 (2016): 670-687. https://doi.org/10.1016/j.enbuild.2016.10.010 
[7] Evans, J. A., E. C. Hammond, A. J. Gigiel, A. M. Fostera, L. Reinholdt, K. Fikiin, and C. Zilio. "Assessment of methods to reduce the energy consumption of food cold stores." Applied Thermal Engineering 62, no. 2 (2014): 697-705. https://doi.org/10.1016/j.applthermaleng.2013.10.023

[8] Chaomuang, Nattawut, Onrawee Laguerre, and Denis Flick. "Dynamic heat transfer modeling of a closed refrigerated display cabinet." Applied Thermal Engineering $161 \quad$ (2019): 114138. https://doi.org/10.1016/i.applthermaleng.2019.114138

[9] Chaomuang, Nattawut, Onrawee Laguerre, and Denis Flick. "A simplified heat transfer model of a closed refrigerated display cabinet." Thermal Science and Engineering Progress 17 (2020): 100494. https://doi.org/10.1016/i.tsep.2020.100494

[10] Evans, J. A., S. Scarcelli, and M. V. L. Swain. "Temperature and energy performance of refrigerated retail display and commercial catering cabinets under test conditions." International Journal of Refrigeration 30, no. 3 (2007): 398-408. https://doi.org/10.1016/j.ijrefrig.2006.10.006

[11] D'Agaro, P., G. Croce, and G. Cortella. "Numerical simulation of glass doors fogging and defogging in refrigerated display cabinets." Applied Thermal Engineering 26, no. $16 \quad$ (2006): 1927-1934. https://doi.org/10.1016/i.applthermaleng.2006.01.014

[12] de Frias, J. Atilio, Yaguang Luo, Bin Zhou, Boce Zhang, David T. Ingram, Keith Vorst, Jeffrey K. Brecht, and John Stommel. "Effect of door opening frequency and duration of an enclosed refrigerated display case on product temperatures and energy consumption." Food Control $111 \quad$ (2020): 107044 https://doi.org/10.1016/i.foodcont.2019.107044

[13] Månsson, Tommie, Adones Rukundo, Magnus Almgren, Philippas Tsigas, Christian Marx, and York Ostermeyer. "Analysis of door openings of refrigerated display cabinets in an operational supermarket." Journal of Building Engineering 26 (2019): 100899. https://doi.org/10.1016/i.jobe.2019.100899

[14] Chaomuang, Nattawut, Denis Flick, Alain Denis, and Onrawee Laguerre. "Experimental analysis of heat transfer and airflow in a closed refrigerated display cabinet." Journal of Food Engineering 244 (2019): 101-114. https://doi.org/10.1016/i.jfoodeng.2018.09.009

[15] de Frias, J. Atilio, Yaguang Luo, Liping Kou, Bin Zhou, and Qin Wang. "Improving spinach quality and reducing energy costs by retrofitting retail open refrigerated cases with doors." Postharvest Biology and Technology 110 (2015): 114-120. https://doi.org/10.1016/i.postharvbio.2015.06.016

[16] DeVetter, Brent M., Seth Kenkel, Shachi Mittal, Rohit Bhargava, and Tomasz P. Wrobel. "Characterization of the structure of low-e substrates and consequences for IR transflection measurements." Vibrational Spectroscopy 91 (2017): 119-127. https://doi.org/10.1016/j.vibspec.2016.09.001

[17] Han, Jun, Lin Lu, and Hongxing Yang. "Numerical evaluation of the mixed convective heat transfer in a double-pane window integrated with see-through a-Si PV cells with low-e coatings." Applied Energy 87, no. 11 (2010): 34313437. https://doi.org/10.1016/j.apenergy.2010.05.025

[18] Schaefer, C., G. Bräuer, and J. Szczyrbowski. "Low emissivity coatings on architectural glass." Surface and Coatings Technology 93, no. 1 (1997): 37-45. https://doi.org/10.1016/S0257-8972(97)00034-0

[19] Solovyev, A. A., S. V. Rabotkin, and N. F. Kovsharov. "Polymer films with multilayer low-E coatings." Materials Science in Semiconductor Processing 38 (2015): 373-380. https://doi.org/10.1016/j.mssp.2015.02.051

[20] Ghosh, S. S., P. K. Biswas, and S. Neogi. "Thermal performance of solar cooker with special cover glass of low-e antimony doped indium oxide (IAO) coating." Applied Thermal Engineering 113 (2017): 103-111. https://doi.org/10.1016/j.applthermaleng.2016.10.185

[21] Abundiz-Cisneros, N., R. Sanginés, R. Rodríguez-López, M. Peralta-Arriola, J. Cruz, and R. Machorro. "Novel Low-E filter for architectural glass pane." Energy and Buildings 206 (2020): 109558. https://doi.org/10.1016/i.enbuild.2019.109558

[22] Tu, Qiu, Kaijun Dong, Deqiu Zou, and Yongman Lin. "Experimental study on multi-split air conditioner with digital scroll compressor." Applied Thermal Engineering 31, no. 14-15 (2011): $2449-2457$. https://doi.org/10.1016/i.applthermaleng.2011.04.010

[23] Huang, Hu, Qihe Li, Dongxue Yuan, Zhenchun Qin, and Zhongbin Zhang. "An experimental study on variable air volume operation of ducted air-conditioning with digital scroll compressor and conventional scroll compressor." Applied Thermal Engineering 28, no. 7 (2008): 761-766. https://doi.org/10.1016/j.applthermaleng.2007.06.018

[24] Saengsikhiao, Piyanut, Juntakan Taweekun, Kittinan Maliwan, Somchai Sae-ung, and Thanansak Theppaya. "The Improvement of Energy Efficiency for Refrigeration System in Thailand Convenience Store by Digital Scroll Compressor." Journal of Advanced Research in Fluid Mechanics and Thermal Sciences 74, no. 1 (2020): $144-150$. https://doi.org/10.37934/arfmts.74.1.144150

[25] Saengsikhiao, Piyanut, Juntakan Taweekun, Kittinan Maliwan, Somchai Sae-ung, and Thanansak Theppaya. "The Replacement of the R404A Refrigeration System with The Environmentally Friendly R448A, to Improve Convenience 
Store Energy Efficiency in Thailand." Journal of Advanced Research in Fluid Mechanics and Thermal Sciences 75, no. 1 (2020): 137-146. https://doi.org/10.37934/arfmts.75.1.137146

[26] Saengsikhiao, Piyanut, Juntakan Taweekun, Kittinan Maliwan, Somchai Sae-ung, and Thanansak Theppaya. "The Performance Simulation of The New R463A HFC/HFO/Carbon Dioxide Refrigerant with Lower GWP, As an Alternate Option for The R404A Refrigeration System." Journal of Advanced Research in Fluid Mechanics and Thermal Sciences 76, no. 1 (2020): 113-123. https://doi.org/10.37934/arfmts.76.1.113123

[27] Saengsikhiao, Piyanut, Juntakan Taweekun, Kittinan Maliwan, Somchai Sae-ung, and Thanansak Theppaya. 2021. "Development of Environmentally Friendly and Energy Efficient Refrigerants for Refrigeration Systems." Energy Engineering 118 (2):411--433. 